University of Nebraska - Lincoln

DigitalCommons@University of Nebraska - Lincoln

\title{
Dryland Soil Carbon and Nitrogen Influenced by Sheep Grazing in the Wheat-Fallow System
}

\author{
Upendra M. Sainju \\ USDA-ARS, upendra.sainju@ars.usda.gov \\ Andrew W. Lenssen \\ USDA-ARS \\ Hayes B. Goosey \\ Montana State University - Bozeman \\ Erin Snyder \\ Montana State University - Bozeman \\ Patrick G. Hatfield \\ Montana State University - Bozeman, hatfield@montana.edu
}

Follow this and additional works at: https://digitalcommons.unl.edu/usdaarsfacpub

Sainju, Upendra M.; Lenssen, Andrew W.; Goosey, Hayes B.; Snyder, Erin; and Hatfield, Patrick G., "Dryland Soil Carbon and Nitrogen Influenced by Sheep Grazing in the Wheat-Fallow System" (2010). Publications from USDA-ARS / UNL Faculty. 1400.

https://digitalcommons.unl.edu/usdaarsfacpub/1400

This Article is brought to you for free and open access by the U.S. Department of Agriculture: Agricultural Research Service, Lincoln, Nebraska at DigitalCommons@University of Nebraska - Lincoln. It has been accepted for inclusion in Publications from USDA-ARS / UNL Faculty by an authorized administrator of DigitalCommons@University of Nebraska - Lincoln. 


\title{
Dryland Soil Carbon and Nitrogen Influenced by Sheep Grazing in the Wheat-Fallow System
}

\author{
Upendra M. Sainju,* Andrew W. Lenssen, Hayes B. Goosey, \\ Erin Snyder, and Patrick G. Hatfield
}

\begin{abstract}
Sheep (Ovis aries) grazing during fallow for weed control in wheat (Triticum aestivum L.)-fallow systems may influence soil C and $\mathrm{N}$ levels and grain yields by returning part of consumed crop residue to the soil through feces and urine. We evaluated the effects of fallow management (sheep grazing [grazing], herbicide application [chemical], and tillage [mechanical]) for weed control and soil water conservation and cropping sequence (continuous spring wheat [CSW], spring wheat-fallow [SW-F], and winter wheat-fal-

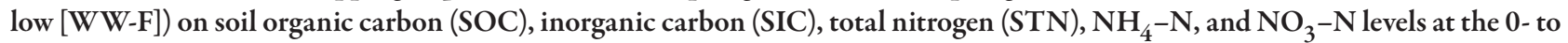
$120-\mathrm{cm}$ depth and wheat yield. The experiment was conducted in a Blackmore silt loam (fine-silty, mixed, superactive, frigid Typic Argiustolls) from 2004 to 2008 in southwestern Montana. Annualized wheat grain and biomass yields were greater in CSW than in SW-F and WW-F and greater in 2004 than in other years. From 2004 to 2007, SOC concentration at 0 - to 15 -cm declined by $2.99 \mathrm{~g} \mathrm{C} \mathrm{kg}^{-1} \mathrm{yr}^{-1}$. In 2008, SOC content at 10 to $120 \mathrm{~cm}$ was greater in the mechanical or chemical than in the grazing treatment in CSW and SW-F. The STN content at 0 to $5 \mathrm{~cm}$ was greater in the chemical and mechanical than in the grazing treatment but at 30 to $60 \mathrm{~cm}$ was greater in the grazing than in the chemical treatment in CSW. From 2004 to $2006, \mathrm{NO}_{3}-\mathrm{N}$ content at 0 to $60 \mathrm{~cm}$ was greater in SW-F or WW-F than in CSW. In 2008, $\mathrm{NO}_{3}-\mathrm{N}$ content at 30 to $120 \mathrm{~cm}$ was greater in CSW and SW-F than in WW-F and at 60 to $90 \mathrm{~cm}$ was greater in the mechanical than in the chemical treatment. The SIC and $\mathrm{NH}_{4}-\mathrm{N}_{\text {contents were largely not }}$ influenced by treatments. Continuous tillage, followed by reduced amount of wheat residue returned to the soil from 2004 to 2007 probably reduced soil $\mathrm{C}$ and $\mathrm{N}$ storage. In contrast, greater amount of $\mathrm{N}$ removed by wheat grain due to continuous cropping probably reduced soil $\mathrm{NO}_{3}-\mathrm{N}$ in CSW. For sustaining wheat yields and maintaining soil $\mathrm{C}$ and $\mathrm{N}$ levels, reduced tillage with continuous cropping and less intensive sheep grazing that increase the amount of wheat residue returned to the soil could be adopted.
\end{abstract}

A NIMAL GRAZING ON CROP RESIDUES and weeds during fallow periods has been a common practice to reduce the cost of feed and increase nutrient cycling in croplands before the introduction of commercial fertilizers in 1950 (Franzluebbers, 2007). Grazing not only sustained crop yields but also increased soil organic matter (Franzluebbers, 2007; Maughan et al., 2009). Extensive application of commercial fertilizers in the 20th century increased crop yields but reduced environmental quality by increasing (i) N leaching from the soil profile to the groundwater, (ii) surface runoff of $\mathrm{N}$ and $\mathrm{P}$ from agricultural lands to streams and lakes, causing eutrophication, and (iii) greenhouse gas, such as $\mathrm{N}_{2} \mathrm{O}$, emission (Franzluebbers, 2007; Herrero et al., 2010). Increased soil acidity following application of commercial fertilizers, especially $\mathrm{N}$ fertilizers, also led to the development of infertile soils that did not respond well to increased fertilizer application for sustaining crop yields (Herrero et al., 2010). In such conditions, integrated crop-livestock system can be used as an option

U.M. Sainju and A.W. Lenssen, USDA-ARS, Northern Plains Agricultural Research Lab., 1500 North Central Ave., Sidney, MT 59270; H.B. Goosey, E. Snyder, and P.G. Hatfield, Montana State Univ., Dep. Animal and Range Sci., 230 Linfield Hall, Bozeman, MT 59717. Received 12 May 2010. ${ }^{*}$ Corresponding author (upendra.sainju@ars.usda.gov).

Published in Agron. J. 102:1553-1561 (2010)

Published online 1 Sept 2010

doi:10.2134/agronj2010.0216

Copyright (C) 2010 by the American Society of Agronomy, 5585 Guilford Road, Madison, WI 53711. All rights reserved. No part of this periodical may be reproduced or transmitted in any form or by any means, electronic or mechanical, including photocopying, recording, or any information storage and retrieval system, without permission in writing from the publisher. to improve soil quality and sustain crop yields (Franzluebbers, 2007; Maughan et al., 2009). Other benefits of this system are: (i) production of crops, meat, and milk, (ii) production of manure to apply as fertilizer, (iii) use of animals as draft power for tillage, and (iv) control of weeds and pests (Franzluebbers, 2007; Hatfield et al., 2007a, 2007c; Herrero et al., 2010).

In the northern Great Plains, sheep grazing during fallow periods in wheat-fallow systems or after grain harvest in continuous wheat systems is often used to control weeds and pests, reduce feed cost, and increase nutrient cycling (Johnson et al., 1997; Entz et al., 2002). In these systems, land is typically fallowed from 8 to $20 \mathrm{mo}$. Fallowing is used to conserve soil water, release plant nutrients, control weeds, increase succeeding crop yields, and reduce the risk of crop failure (Aase and Pikul, 1995; Jones and Popham, 1997). Using tillage and herbicides to control weeds during fallow have been effective but are expensive, resulting in some of the highest variable costs for small grain production in Montana (Johnson et al., 1997). Other disadvantages of using these practices are the exposure of soil to erosion due to tillage and increased risk of contamination of herbicides in soil, water, and human and animal health (Fenster, 1997).

Goosey et al. (2005) and Hatfield et al. (2007a, 2007c) reported that sheep grazing during fallow periods effectively controlled weeds and insects, such as wheat stem saw fly [Cephus cinctus Norton (Hymenoptera: Cephidae)] compared with nongrazed, tilled, or burned treatments. Although grazing can reduce

Abbreviations: Chemical, weed control with herbicide application; CSW, continuous spring wheat; Grazing, weed control with sheep grazing; Mechanical, weed control with tillage; SIC, soil inorganic carbon; SOC, soil organic carbon; STN, soil total nitrogen; SW-F, spring wheat-fallow; WW-F, winter wheat-fallow. 
Table I. Monthly total precipitation from 2004 to 2008 near the experimental site.

\begin{tabular}{lrrrrrr}
\hline \multicolumn{1}{c}{ Month } & $\mathbf{2 0 0 4}$ & $\mathbf{2 0 0 5}$ & $\mathbf{2 0 0 6}$ & $\mathbf{2 0 0 7}$ & $\mathbf{2 0 0 8}$ & I I 3-yr avg. \\
\cline { 2 - 5 } & & & & $\mathrm{mm}$ & & \\
January & 7.4 & 7.1 & 11.2 & 3.6 & 8.1 & 22.4 \\
February & 13.7 & 6.9 & 2.0 & 23.9 & 6.9 & 18.5 \\
March & 6.4 & 22.1 & 18.5 & 10.4 & 13.2 & 33.8 \\
April & 32.8 & 41.9 & 66.3 & 47.5 & 54.3 & 46.2 \\
May & 72.9 & 36.6 & 33.5 & 70.1 & 70.6 & 72.6 \\
June & 66.3 & 41.9 & 68.3 & 58.9 & 73.4 & 73.7 \\
July & 45.0 & 16.5 & 16.5 & 2.8 & 17.8 & 34.5 \\
August & 39.6 & 31.2 & 18.3 & 23.9 & 13.7 & 31.5 \\
September & 36.3 & 22.6 & 25.9 & 30.2 & 8.9 & 43.9 \\
October & 31.0 & 46.7 & 72.6 & 52.3 & 8.4 & 38.1 \\
November & 5.3 & 29.7 & 5.3 & 20.8 & 24.4 & 27.7 \\
December & 5.8 & 17.3 & 6.9 & 5.8 & 14.5 & 21.8 \\
Total & 362.5 & 320.5 & 345.4 & 350.2 & $3 \mid 4.5$ & 464.8 \\
\hline
\end{tabular}

the quantity of crop residue returned to the soil, the number of sheep grazed per unit area can be adjusted in such a way that crop residue cover in the grazing treatment will be similar to that in the conservation tillage system where soil erosion is minimal (Hatfield et al., 2007c). Animal feces and urine returned to the soil during grazing can enrich soil nutrients, improve soil quality, and increase crop yields (Tracy and Zhang, 2008; Maughan et al., 2009). The distribution of feces and urine by animals during grazing at the soil surface can be uneven; however, distribution can be more uniform with sheep than with cattle (Bos taurus) grazing (Abaye et al., 1997). Hatfield et al. (2007b) and Snyder et al. (2007) reported that sheep grazing during fallow to control weeds did not influence soil organic matter, $\mathrm{NO}_{3}-\mathrm{N}$ content, and wheat yields compared with nongrazed treatment in western Montana. Abaye et al. (1997) found that grazing sheep and cattle together increased soil bulk density and organic matter and grass yields compared with grazing sheep or cattle alone.

The conventional-tilled wheat-fallow systems in the northern Great Plains have resulted in reduced crop yields and soil organic matter due to absence of crops during fallow (Aase and Pikul, 1995; Halvorson et al., 2002; Sainju et al., 2009b). Intensive tillage increases the oxidation of soil organic matter (Bowman et al., 1999; Schomberg and Jones, 1999). Fallowing reduces organic matter by reducing the amount of nonharvested plant residue returned to the soil and increasing soil temperature and water content that increase microbial activity (Campbell et al., 2000; Halvorson et al., 2002). Extending the fallow period by reducing cropping intensity can reduce soil water storage efficiency, increase saline seeps development, and reduce soil organic matter (Tanaka and Aase, 1987; Black and Bauer, 1988). In contrast, reduced tillage and increased cropping intensity can increase crop yields and soil C and N storage (Aase and Pikul, 1995; Halvorson et al., 2002; Sainju et al., 2007, 2009b).

Soil $\mathrm{C}$ and $\mathrm{N}$ storage are key indicators of soil quality and productivity (Bauer and Black, 1994). Increases in C and N storage can increase soil $\mathrm{C}$ and $\mathrm{N}$ sequestration to mitigate greenhouse gases, such as $\mathrm{CO}_{2}$ and $\mathrm{N}_{2} \mathrm{O}$ emissions, from agricultural ecosystems and reduce $\mathrm{N}$ fertilization rates to crops and the potential for $\mathrm{N}$ leaching (Halvorson et al., 2002; Sainju et al., 2007, 2009a). An increase in SOC content by $580 \mathrm{~kg} \mathrm{C}$ $\mathrm{ha}^{-1}$ in the surface $3 \mathrm{~cm}$ of the soil can increase wheat grain yield by $15.6 \mathrm{~kg} \mathrm{ha}^{-1}$, primarily due to enhanced soil structure and improved soil water-nutrient-crop productivity relationships (Bauer and Black, 1994). Although mechanical farming system is commonly used to grow dryland crops in the northern Great Plains, attention has been drawn to use the chemical system which produces similar or better crop yields and reduces fuel cost, soil erosion, and organic matter mineralization compared with the mechanical system (Aase and Pikul, 1995, Halvorson et al., 2002; Sainju et al., 2007, 2009a). Because of the similar or better effects on soil organic matter, nutrient cycling, and crop yields and improved weed and pest control, sheep grazing during fallow is getting increasingly popular to sustain dryland soil quality and crop yields in the northern Great Plains (Hatfield et al., 2007a, 2007c; Snyder et al., 2007; Herrero et al., 2010).

Little information is available on the effect of sheep grazing on dryland soil $\mathrm{C}$ and $\mathrm{N}$ levels and crop yields compared with tillage or herbicide application to control weeds in wheat-fallow and continuous wheat systems. We hypothesized that sheep grazing would result in similar or increased dryland soil $\mathrm{C}$ and $\mathrm{N}$ levels and wheat yields compared with tillage or herbicide application and that the effect will be more pronounced in CSW than in SW-F and WW-F. Our objectives were to: (i) evaluate the effects of fallow management for weed control (sheep grazing [grazing], herbicide application [chemical], and tillage [mechanical]) and cropping systems (CSW, SW-F, and WW-F) on dryland SOC, SIC, STN, $\mathrm{NH}_{4}-\mathrm{N}$, and $\mathrm{NO}_{3}-\mathrm{N}$ levels at the 0 - to $120-\mathrm{cm}$ depth and wheat grain and biomass yields from 2004 to 2008 and (ii) relate soil C and N levels with wheat grain and biomass yields in the southwestern Montana.

\section{MATERIALS AND METHODS Site Description and Treatments}

The experiment was conducted from 2004 to 2008 at the Fort Ellis Research and Extension Center, Montana State University, Bozeman, MT ( $45^{\circ} 40^{\prime} \mathrm{N}, 111^{\circ} 2^{\prime} \mathrm{W}$; altitude $\left.1468 \mathrm{~m}\right)$. The site has mean monthly air temperature ranging from $-5.7^{\circ} \mathrm{C}$ in January to $18.9^{\circ} \mathrm{C}$ in July. The mean annual precipitation (113-yr average) is $465 \mathrm{~mm}, 60 \%$ of which occurs during the crop growing season (April-September) (Table 1). The soil is a Blackmore silt loam with 0 to $4 \%$ slopes and contains $250 \mathrm{~g} \mathrm{~kg}^{-1}$ sand, $500 \mathrm{~g} \mathrm{~kg}^{-1}$ silt, and $250 \mathrm{~g} \mathrm{~kg}^{-1}$ clay at 0 to $15 \mathrm{~cm}$. The SOC concentrations at 0 to $15 \mathrm{~cm}$ and 15 to $30 \mathrm{~cm}$ taken from two composite cores per plot in the spring 2004 before the initiation of the experiment were 33.2 and $17.5 \mathrm{~g} \mathrm{C} \mathrm{kg}^{-1}$, respectively. Similarly, soil $\mathrm{pH}$ at 0 to $15 \mathrm{~cm}$ and 15 to $30 \mathrm{~cm}$ were 6.68 and 6.46 , respectively. Previous cropping history for the last $10 \mathrm{yr}$ was perennial grass pasture containing a mixture of smooth bromegrass (Bromus inermis L.), intermediate wheatgrass (Thinopyrum intermedium L.), and Canada bluegrass (Poa compressa L.), followed by $1 \mathrm{yr}$ of tilled fallow.

Treatments consisted of three fallow management practices for weed control and soil water conservation (sheep grazing [grazing], herbicide application [chemical], and tillage [mechanical]) as the main plot and three cropping sequences (continuous spring wheat [CSW], spring wheat-fallow [SW-F], and winter wheat-fallow [WW-F]) as the split-plot treatment arranged in a randomized complete block with three replications. The grazing treatment consisted of grazing with a group of western white-faced sheep at a stocking rate of 29 to 153 sheep day ha ${ }^{-1}$ during fallow periods in fenced plots. Sheep grazing period on weeds and wheat residue 
after grain harvest ranged from 3 out of 8 mo of fallow in CSW to 10 out of 20 mo in SW-F. Grazing ended when about $47 \mathrm{~kg} \mathrm{ha}^{-1}$ or less of wheat residue and weeds remained in the plot. The chemical treatment consisted of applying herbicides, such as a mixture of glyphosate [ $N$-(phosphonomethyl)-glycin] at $1.17 \mathrm{~L} \mathrm{ha}^{-1}$ and dimethylamine salt of dicamba (3, 6-dichloro-o-anisic acid) at $1.75 \mathrm{~L} \mathrm{ha}^{-1}$, to control weeds during fallow periods as needed. The mechanical treatment consisted of tilling the plots two to three times during fallow and planting with Flexicoil harrow (John Derre 100, Kennedy, MN) to a depth $15 \mathrm{~cm}$ for controlling weeds and seedbed preparation. Each phase of the cropping sequence was present in each year. The split plot size was 91.4 by $15.2 \mathrm{~m}$.

\section{Crop Management}

From 2004 to 2008 , the rates of $\mathrm{N}$ fertilizer applied to spring wheat and winter wheat ranged from $200 \mathrm{~kg} \mathrm{~N} \mathrm{ha}^{-1}$ in CSW and WW-F to $250 \mathrm{~kg} \mathrm{~N}^{-1}$ in SW-F. The rates depended on yield goals which ranged from $3.9 \mathrm{Mg} \mathrm{ha}^{-1}$ in CSW to $4.8 \mathrm{Mg} \mathrm{ha}^{-1}$ in SW-F and WW-F. Soil $\mathrm{NO}_{3}-\mathrm{N}$ content to a depth of $60 \mathrm{~cm}$ measured after grain harvest in the fall every year was adjusted to $\mathrm{N}$ rate before $\mathrm{N}$ fertilizer was applied to spring and winter wheat. Nitrogen fertilizer as urea $(45 \% \mathrm{~N})$ was broadcast in April-May to both spring and winter wheat. For spring wheat, $\mathrm{N}$ fertilizer was incorporated to a depth of $15 \mathrm{~cm}$ using a Flexicoil harrow. For winter wheat, $\mathrm{N}$ fertilizer was applied at the surface. Since the soil contained higher levels of extractable $\mathrm{P}$ and $\mathrm{K}$ (61.2 and $41.6 \mathrm{mg} \mathrm{P} \mathrm{kg}^{-1}$ and 424 and $296 \mathrm{mg} \mathrm{K} \mathrm{kg}^{-1}$ at 0 to 15 and 15 to $30 \mathrm{~cm}$, respectively) in 2004, no P and K fertilizers were applied.

Spring wheat (cultivar McNeal, Foundation Seed, Montana State Univ., Bozeman, MT) was planted at $90 \mathrm{~kg} \mathrm{ha}^{-1}$ in late April-early May and winter wheat (cultivar Promontory, Foundation Seed, Montana Sate Univ., Bozeman, MT) was planted at $73 \mathrm{~kg} \mathrm{ha}^{-1}$ in late September-early October using a double disc opener with a row spacing of $30 \mathrm{~cm}$. Growing season broadleaf weeds were controlled with selective post-emergence herbicides. In late August-early September, $2 \mathrm{~d}$ before grain harvest, total wheat yield containing stems, leaves, and grains were harvested from two $0.5 \mathrm{~m}^{2}$ quadrats. These were oven-dried at $60^{\circ} \mathrm{C}$ for 2 to $3 \mathrm{~d}$ and dry matter yield was determined after weighing. Grain yields for spring and winter wheat (at $12-13 \%$ moisture content) were determined from an area of $1389 \mathrm{~m}^{2}$ using a combine harvester in each year. Biomass (stems + leaves) yield was determined after deducting grain yield from total yield. After grain harvest, wheat residue containing stems and leaves were returned to the soil, except in 2004 when straw from nongrazed plots was removed. All cropped plots were tilled with a tandem disk in the late fall following harvest.

\section{Soil Sampling and Analysis}

In September-October, 2004 to 2007, soil samples were collected from the 0 - to $60-\mathrm{cm}$ depth with a hydraulic probe $(5 \mathrm{~cm}$ i.d.) attached to a truck from five places within the plot. These were divided into 0 to 15,15 to 30 , and 30 to $60 \mathrm{~cm}$ and composited by depth. In 2008, samples were collected from 0 to $120 \mathrm{~cm}$ from five places within the plot, separated into 0 to 5,5 to 10,10 to 30,30 to 60,60 to 90 , and 90 to $120 \mathrm{~cm}$ and composited by depth. Samples were air-dried, ground, and sieved to $2 \mathrm{~mm}$ for determining soil $\mathrm{C}$ and $\mathrm{N}$ concentrations. In 2008, an additional undisturbed soil core $(5 \mathrm{~cm} \mathrm{i.d}$.) was collected from 0 to 5,5 to 10,10 to 30,30 to 60,60 to 90 , and 90 to $120 \mathrm{~cm}$ to determine bulk density by dividing the mass of the oven-dried soil at $105^{\circ} \mathrm{C}$ by the volume of the core. Because of the nonsignificant effects of treatments and interactions, bulk density values of 1.20, 1.34, $1.61,1.61,1.53$, and $1.46 \mathrm{Mg} \mathrm{m}^{-3}$ at 0 to 5,5 to 10,10 to 30,30 to 60,60 to 90 , and 90 to $120 \mathrm{~cm}$, respectively, were used to convert concentrations $\left(\mathrm{mg} \mathrm{kg}^{-1}\right.$ or $\left.\mathrm{g} \mathrm{kg}^{-1}\right)$ of $\mathrm{C}$ and $\mathrm{N}$ to contents $\left(\mathrm{kg} \mathrm{ha}^{-1}\right.$ or $\left.\mathrm{Mg} \mathrm{ha}^{-1}\right)$ for samples in 2008.

Total C concentration $\left(\mathrm{g} \mathrm{C} \mathrm{kg}^{-1}\right)$ in soil samples was determined by using a dry combustion $\mathrm{C}$ and $\mathrm{N}$ analyzer (LECO Corp., St Joseph, MI) after grinding the sample to $<0.5 \mathrm{~mm}$ and pretreating the soil with and without $5 \% \mathrm{H}_{2} \mathrm{SO}_{3}$ to remove inorganic C (Nelson and Sommers, 1996). The SOC was determined as $\mathrm{C}$ concentration in the acid-treated soil. The SIC was determined by deducting SOC from total C. Because the $\mathrm{pH}$ of soil samples at the 0 to $60 \mathrm{~cm}$ depth was $<7.0$, total C concentration determined for samples from 2004 to 2007 was considered as SOC concentration (Nelson and Sommers, 1996). The STN concentration was determined in the nonacid-treated samples by using $\mathrm{C}$ and $\mathrm{N}$ analyzer as above. The $\mathrm{NH}_{4}-\mathrm{N}$ and $\mathrm{NO}_{3}-\mathrm{N}$ concentrations in samples were determined by using the autoanalyzer (Lachat Instrument, Loveland, CO) after extracting the soil with $2 \mathrm{M} \mathrm{KCl}$ for $1 \mathrm{~h}$. The SOC, SIC, STN, $\mathrm{NH}_{4}-\mathrm{N}$, and $\mathrm{NO}_{3}-\mathrm{N}$ contents $\left(\mathrm{kg} \mathrm{ha}^{-1}\right.$ or $\mathrm{Mg} \mathrm{ha}^{-1}$ ) in 2008 were determined by multiplying their concentrations $\left(\mathrm{mg} \mathrm{kg}^{-1}\right.$ or $\mathrm{g} \mathrm{kg}^{-1}$ ) by bulk density and thickness of the soil layer. Since $\mathrm{NO}_{3}-\mathrm{N}$ levels in soil samples from 2004 to 2007 were analyzed by commercial laboratory (Agvise Laboratories, Northwood, $\mathrm{ND}$ ), values for $\mathrm{NO}_{3}-\mathrm{N}$ in these years were reported in content $\left(\mathrm{kg} \mathrm{N} \mathrm{ha}^{-1}\right)$ instead of concentration $\left(\mathrm{mg} \mathrm{kg}^{-1}\right)$, in contrast to that reported for SOC.

Because of the manpower and/or budget constraints, only soil samples at 0 to $15 \mathrm{~cm}$ from 2004 to 2006 , at 0 to $60 \mathrm{~cm}$ in 2007 , and at 0 to $120 \mathrm{~cm}$ in 2008 were analyzed for SOC. Similarly, samples at 0 to $120 \mathrm{~cm}$ in 2008 were analyzed for SIC, STN, and $\mathrm{NH}_{4}-\mathrm{N}$. For $\mathrm{NO}_{3}-\mathrm{N}$, samples at 0 to $60 \mathrm{~cm}$ from 2004 to 2007 and at 0 to $120 \mathrm{~cm}$ in 2008 were used for analysis.

\section{Data Analysis}

Data for soil C and $\mathrm{N}$ levels at a depth and wheat grain and biomass yields were analyzed using the MIXED procedure of SAS (Littell et al., 1996). Fallow management was considered as the main plot variable and fixed effect, cropping sequence as the split-plot variable and another fixed effect, and year as the repeated measure variable. Random variables were replication and replication $\times$ fallow management. Values were averaged across cropping sequence phases and average value was used for a cropping sequence for the analysis. For wheat grain and biomass yields, data were annualized by dividing the values by 1 in CSW and 2 in SW-F and WW-F, since wheat was absent during fallow in SW-F and WW-F. Means were separated by using the least square means test when treatments and interactions were significant (Littell et al., 1996). Statistical significance was evaluated at $P \leq 0.05$, unless otherwise stated. Linear regression analysis was used to determine the relationship between year, wheat grain and biomass yields, and SOC and $\mathrm{NO}_{3}-\mathrm{N}$ levels. 
Table 2. Effects of cropping sequence and fallow management practice on annualized wheat grain and biomass (stems + leaves) yields from 2004 to 2008 .

\begin{tabular}{|c|c|c|c|c|c|c|c|}
\hline \multirow[b]{2}{*}{ Year } & \multicolumn{3}{|c|}{ Cropping sequence } & \multicolumn{3}{|c|}{ Fallow management $\ddagger$} & \multirow{2}{*}{ Mean } \\
\hline & CSW & SW-F & WW-F & Chem. & Mech. & Graz. & \\
\hline & \multicolumn{7}{|c|}{$\mathrm{Mg} \mathrm{ha}^{-1}$} \\
\hline & \multicolumn{7}{|c|}{ Annualized grain yield } \\
\hline 2004 & $5.55 \mathrm{a} \S \mathrm{A} \mathbb{T}$ & $2.90 \mathrm{aC}$ & $3.53 \mathrm{aB}$ & $3.92 \mathrm{aA}$ & $4.0 \mathrm{IaA}$ & $4.05 \mathrm{aA}$ & $3.99 a$ \\
\hline 2005 & $2.68 \mathrm{bA}$ & $1.83 \mathrm{bB}$ & $1.15 \mathrm{eC}$ & $1.84 \mathrm{cA}$ & $1.92 \mathrm{bA}$ & $1.90 \mathrm{bA}$ & $1.89 \mathrm{~b}$ \\
\hline 2006 & $2.57 \mathrm{bA}$ & $\mathrm{I} .45 \mathrm{cB}$ & $1.70 \mathrm{~dB}$ & I.89cA & $1.90 \mathrm{bA}$ & $1.92 \mathrm{bA}$ & $1.90 \mathrm{~b}$ \\
\hline 2007 & $1.86 \mathrm{cB}$ & $1.18 \mathrm{cC}$ & $2.95 \mathrm{bA}$ & I.89cA & $2.03 \mathrm{bA}$ & $2.00 \mathrm{bA}$ & $2.00 \mathrm{~b}$ \\
\hline 2008 & $2.6 \mathrm{IbA}$ & $1.56 \mathrm{bcC}$ & $2.22 \mathrm{cB}$ & $2.09 \mathrm{bA}$ & $2.17 \mathrm{bA}$ & $2.14 \mathrm{bA}$ & $2.13 b$ \\
\hline \multirow[t]{2}{*}{ Mean } & $3.05 \mathrm{~A}$ & $\mathrm{I} .78 \mathrm{C}$ & $2.31 \mathrm{~B}$ & $2.32 \mathrm{~A}$ & $2.42 \mathrm{~A}$ & $2.40 \mathrm{~A}$ & \\
\hline & \multicolumn{7}{|c|}{ Annualized biomass yield } \\
\hline 2004 & $6.60 \mathrm{aA}$ & $3.10 \mathrm{aC}$ & $3.57 \mathrm{aB}$ & $3.6 \mathrm{laAB}$ & $3.4 \mathrm{IaB}$ & $3.89 \mathrm{aA}$ & $4.42 \mathrm{a}$ \\
\hline 2005 & $3.28 \mathrm{bA}$ & $1.65 \mathrm{bB}$ & $1.94 \mathrm{bcB}$ & $2.52 \mathrm{bA}$ & $2.17 \mathrm{bcA}$ & $2.19 \mathrm{bA}$ & $2.29 b$ \\
\hline 2006 & $2.96 \mathrm{cA}$ & $1.57 \mathrm{bcB}$ & $1.64 c B$ & $1.79 b B$ & $2.5 \mathrm{IbA}$ & $1.87 \mathrm{bcB}$ & $2.06 \mathrm{bc}$ \\
\hline 2007 & $2.18 \mathrm{dA}$ & $1.55 \mathrm{bcB}$ & $2.25 \mathrm{bA}$ & $1.78 \mathrm{bA}$ & $2.2 \mathrm{IbcA}$ & $2.00 \mathrm{bA}$ & $2.00 c$ \\
\hline 2008 & $1.92 \mathrm{dA}$ & $1.17 c B$ & $1.49 \mathrm{cAB}$ & $1.08 \mathrm{cB}$ & $1.91 \mathrm{cA}$ & $1.58 \mathrm{cA}$ & $\mathrm{I} .53 \mathrm{~d}$ \\
\hline Mean & $2.58 \mathrm{~A}$ & $\mathrm{I} .49 \mathrm{C}$ & I.83B & $1.79 \mathrm{~B}$ & $2.20 \mathrm{~A}$ & $1.91 \mathrm{~B}$ & \\
\hline
\end{tabular}

† Cropping sequence are CSW, continuous spring wheat; SW-F, spring wheat-fallow; and WW-F, winter wheat-fallow.

‡ Fallow management practices are Chem., chemical where weeds were controlled with herbicides; Graz., grazing where weeds were controlled with sheep grazing; and Mech., mechanical where weeds were controlled with tillage.

$\S$ Numbers followed by different lowercase letters within a column in a set are significantly different at $P=0.05$ by the least square means test.

II Numbers followed by different uppercase letters within a row in a set are significantly different at $P=0.05$ by the least square means test.

\section{RESULTS AND DISCUSSION}

\section{Annualized Wheat Grain and Biomass Yields}

Annualized wheat grain and biomass yields varied significantly among cropping sequences and years and biomass yield among fallow management practices (data not shown). Interactions were significant for cropping sequence $\times$ year for grain and biomass yields and fallow management $\times$ year for biomass yield.

Averaged across fallow management practices, both annualized grain and biomass yields were greater in CSW than in SW-F and WW-F in all years, except in 2007 when yields were greater in CSW and WW-F than in SW-F (Table 2). Averaged across cropping sequences, grain yield did not differ among fallow management practices in all years. In contrast, biomass yield was greater in the grazing than in the mechanical treatment in 2004 and greater in the grazing and mechanical than in the chemical treatment in 2008. In 2006, biomass yield was greater in the mechanical than in the chemical and grazing treatments. Both grain and biomass yields were greater in 2004 than in other years, regardless of cropping sequences and fallow management practices. Averaged across fallow management practices and years, grain and biomass yields were in the order: CSW > WW-F > SW-F. Averaged across cropping sequences and years, biomass yield was in the order: mechanical treatment $>$ grazing treatment $=$ chemical treatment .

The greater annualized wheat grain and biomass yields in CSW than in SW-F and WW-F in all years, except in 2007, was due to continuous cropping. Absence of crops during fallow reduced annualized yields in SW-F and WW-F. This is similar to that reported by various researchers in dryland cropping systems in the northern Great Plains (Aase and Pikul, 1995; Lenssen et al., 2007; Sainju et al., 2009b). In 2007, lower yields in CSW and SW-F than in WW-F were probably due to distribution of precipitation during the crop growing season. Although growing season precipitation for spring wheat (April-September) in CSW and SW-F in 2007 was comparable with other years, monthly precipitation in July was $2.8 \mathrm{~mm}$ in 2007 compared with 16.5 to $45.0 \mathrm{~mm}$ in other years (Table 1). Lower precipitation in July, active wheat growing period, probably reduced spring wheat yields in CSW and SW-F in 2007. Growing season precipitation for winter wheat in WW-F (October of the current year to September of the following year) was much higher than for spring wheat in CSW and SW-F because of longer growing period. In dryland cropping systems, growing season precipitation amount and distribution can influence crop yields (Halvorson et al., 2000; Sainju et al., 2009b). Greater wheat grain and biomass yields in 2004 than in other years could be a result of increased precipitation (Table 1 ) and higher soil $\mathrm{NO}_{3}-\mathrm{N}$ concentration, as shown below.

The nonsignificant effect of fallow management on wheat grain yield suggests that sheep grazing did not alter grain yields compared with tillage and herbicide application methods of weed control. Several researchers (Redmon et al., 1995; Landau et al., 2007; Snyder et al., 2007) have also reported that wheat grain yields were similar to or greater with animal grazing than without. In contrast, greater biomass yield in the mechanical than in the chemical and grazing treatments was probably a result of increased root growth due to tillage. The result suggests that wheat grain and biomass may not always grow in the same proportion; rather their growth may be altered by management practices. Variations in amounts of wheat biomass residue returned to the soil among treatments and removal of residue due to consumption by sheep during grazing are expected to influence soil $\mathrm{C}$ and $\mathrm{N}$ levels, as discussed below.

\section{Soil Organic and Inorganic Carbon}

From 2004 to 2007 , SOC concentration at 0 to 15,15 to 30 , and 30 to $60 \mathrm{~cm}$ was not influenced by treatments but the concentration at 0 to $15 \mathrm{~cm}$ was significant for the year (Table 3). Averaged across treatments, SOC concentration at 0 to $15 \mathrm{~cm}$ decreased linearly from 2004 to 2007 at the rate of $2.99 \mathrm{~g} \mathrm{C} \mathrm{kg}^{-1} \mathrm{yr}^{-1}\left(\mathrm{R}^{2}=0.99, P \leq 0.01, \mathrm{n}=4\right)$. The SOC concentration at 0 to $15 \mathrm{~cm}$ was also correlated with biomass 
yield $\left(\mathrm{R}^{2}=0.73, P \leq 0.15, \mathrm{n}=4\right)$. A decrease in biomass yield by $1 \mathrm{Mg} \mathrm{ha}^{-1} \mathrm{yr}^{-1}$ decreased SOC by $2.86 \mathrm{~g} \mathrm{C} \mathrm{kg}^{-1} \mathrm{yr}^{-1}$.

In 2008, SOC content at 10 to 30 and 90 to $120 \mathrm{~cm}$ was influenced by fallow management (Table 4). The cropping sequence $x$ fallow management interaction was significant for SOC content at 10 to 30,30 to 60,90 to 120 , and 0 to $120 \mathrm{~cm}$ and SIC content at 30 to $60 \mathrm{~cm}$. Treatments did not influence SIC at all depths.

In 2008, SOC content at 10 to 30,30 to 60,90 to 120 , and 0 to $120 \mathrm{~cm}$ was greater in the mechanical than in the chemical or grazing treatment in CSW (Table 5). In SW-F, SOC content at 10 to 30,30 to 60 , and 0 to $120 \mathrm{~cm}$ was greater in the chemical than in the mechanical or grazing treatment. Similarly, in WW-F, SOC content at 10 to $30 \mathrm{~cm}$ was greater in the chemical than in the grazing treatment. Averaged across cropping sequences, $\mathrm{SOC}$ content at 10 to $30 \mathrm{~cm}$ was greater in the chemical than in the grazing treatment but at 90 to $120 \mathrm{~cm}$ was greater in the mechanical than in the chemical treatment. The SIC content at 30 to $60 \mathrm{~cm}$ was greater in the grazing than in the chemical and mechanical treatment in CSW (Table 6). Although not significant, similar variation among fallow management practices occurred for SIC at 10 to $30 \mathrm{~cm}$ in CSW. Presence of SIC was pronounced more below $60 \mathrm{~cm}$.

The nonsignificant differences in SOC concentration at 0 to 60 $\mathrm{cm}$ among treatments from 2004 to 2007 (Table 3) indicates that soil organic $\mathrm{Clevel}$ was not influenced by cropping sequence and fallow management practices during the first $4 \mathrm{yr}$ of the experiment. Several researchers (Halvorson et al., 2002; Ortega et al., 2002; Sainju et al., 2006) also reported that SOC levels did not significantly alter after 5 to 8 yr of changes in cropping sequence in dryland cropping systems in the northern and central Great Plains. A strong linear decrease in SOC concentration from 2004 to 2007 (Table 3), however, reveals that SOC declined probably because conversion of pastureland at the initiation of the experiment to cropland due to continuous tillage for wheat planting mineralized soil organic matter. Although lands were not tilled during fallow periods in the chemical and sheep grazing treatments, plots were tilled in the spring for spring wheat planting, in the fall for winter wheat planting, and during fallow in the mechanical treatment to control weeds. Franzluebbers and Stuedemann (2008) reported that tilling the pastureland for planting crops significantly reduced SOC after 1 yr and reduction further increased as tillage continued over time. Furthermore, removal of wheat biomass for hay in 2004, reduced biomass residue returned to the soil from 2005 to 2007 (Table 2), and consumption of residue by sheep during grazing may also have accelerated the reduction in SOC, since SOC is directly related with the amount of crop residue returned to the soil (Halvorson et al., 2002; Sainju et al., 2009b).

The greater SOC content at 10 to $120 \mathrm{~cm}$ in the mechanical than in the chemical treatment in CSW in 2008 (Table 5) was probably a result of residue incorporation to a greater depth and/or greater root growth at the subsoil layers due to tillage, since the mechanical treatment had greater tillage frequency for weed control than the chemical treatment and biomass yield was greater in the mechanical than in chemical treatment (Table 2). Tillage increases SOC in subsoil layers compared with no-tillage due to residue incorporation to greater depths (Franzluebbers and Stuedemann, 2008). In contrast, greater $\mathrm{SOC}$ content at 10 to $60 \mathrm{~cm}$ in the chemical than in the mechanical treatment in SW-F could be due to greater root growth in the subsoil layers, since the mulch effect of the residue accumulated at the soil surface during fallow in the chemical treatment
Table 3. Effects of cropping sequence and fallow management practice on soil organic carbon (SOC) concentration at the 0 to $60-\mathrm{cm}$ depth from 2004 to 2007.

\begin{tabular}{|c|c|c|c|}
\hline \multirow[b]{2}{*}{ Treatment } & \multicolumn{3}{|c|}{ SOC concentration } \\
\hline & $0-15 \mathrm{~cm}$ & $15-30 \mathrm{~cm}$ & $30-60 \mathrm{~cm}$ \\
\hline & $\longrightarrow$ & $-\mathrm{gC} \mathrm{kg}^{-1}$ & 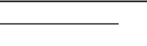 \\
\hline \multicolumn{4}{|l|}{ Cropping sequence $\dagger$} \\
\hline CSW & $27.9 a \S$ & I7.0a & $10.7 \mathrm{a}$ \\
\hline SW-F & $27.7 \mathrm{a}$ & $16.7 \mathrm{a}$ & $11.9 \mathrm{a}$ \\
\hline WW-F & $28.3 a$ & $16.7 \mathrm{a}$ & $10.3 \mathrm{a}$ \\
\hline \multicolumn{4}{|l|}{ Fallow managementł } \\
\hline Chem. & $29.8 a$ & $17.4 \mathrm{a}$ & $10.2 \mathrm{a}$ \\
\hline Mech. & $27.6 \mathrm{a}$ & $16.4 \mathrm{a}$ & $11.4 \mathrm{a}$ \\
\hline Graz. & $26.5 \mathrm{a}$ & $16.6 \mathrm{a}$ & $10.4 \mathrm{a}$ \\
\hline \multicolumn{4}{|l|}{ Year } \\
\hline 2004 & $32.6 \mathrm{a}$ & nd $\boldsymbol{T}$ & nd \\
\hline 2005 & $29.4 b$ & nd & nd \\
\hline 2006 & $26.2 c$ & nd & nd \\
\hline 2007 & $23.7 d$ & 16.8 & 11.0 \\
\hline \multicolumn{4}{|l|}{ Analysis of variance } \\
\hline Cropping sequence (CS) & nstt & ns & ns \\
\hline Fallow management (FM) & ns & ns & ns \\
\hline $\mathrm{CS} \times \mathrm{FM}$ & ns & ns & ns \\
\hline Year (Yr) & $* * *$ & nd & nd \\
\hline $\mathrm{CS} \times \mathrm{Yr}$ & ns & nd & nd \\
\hline $\mathrm{FM} \times \mathrm{Yr}$ & ns & nd & nd \\
\hline $\mathrm{CS} \times \mathrm{FM} \times \mathrm{Yr}$ & ns & nd & nd \\
\hline \multicolumn{4}{|l|}{ *** Significant at $P \leq 0.001$} \\
\hline \multicolumn{4}{|c|}{$\begin{array}{l}\text { † Cropping sequence are CSW, continuous spring wheat; SW-F, spring wheat- } \\
\text { fallow; and WW-F, winter wheat-fallow. }\end{array}$} \\
\hline \multicolumn{4}{|c|}{$\begin{array}{l}\text { ‡ Fallow management practices are Chem., chemical where weeds were con- } \\
\text { trolled with herbicides; Graz., grazing where weeds were controlled with sheep } \\
\text { grazing; and Mech., mechanical where weeds were controlled with tillage. }\end{array}$} \\
\hline \multicolumn{4}{|c|}{$\begin{array}{l}\S \text { Numbers followed by different letters within a column in a set are significantly } \\
\text { different at } P=0.05 \text { by the least square means test. }\end{array}$} \\
\hline \multicolumn{4}{|c|}{ I Not determined. } \\
\hline †† Not significant. & & & \\
\hline
\end{tabular}

can conserve soil water and promote root growth of the succeeding crop (Merrill et al., 1996). Lower SOC content at 0 to $120 \mathrm{~cm}$ in the grazing than in the chemical or mechanical treatment in CSW and SW-F suggests that grazing reduced SOC by removing crop residue, a result of consumption of residue by sheep. Although part of residue $C$ was returned to the soil through sheep feces and urines, they may not be enough to alter $\mathrm{C}$ levels in the soil. It seems that most of the wheat residue was used by sheep to increase live weight. The finding was in contrast to that observed by Hatfield et al. (2007c) who reported that SOC was not different among sheep-grazed, nongrazed, and tilled treatments in dryland cropping systems in northwestern Montana. The variations in the duration of the experiment and soil and climatic conditions among locations may have varying effects on crop biomass production and SOC storage and mineralization, since Hatfield et al. (2007c) conducted experiment for $2 \mathrm{yr}$ compared with $5 \mathrm{yr}$ in this study.

Because $\mathrm{pH}$ of the soil at 0 to $60 \mathrm{~cm}$ was $<7.0$, SIC content remained lower at this depth (Table 6). The content, however, increased dramatically below $60 \mathrm{~cm}$ to such an extent that the amount was similar to SOC content (Table 5). The greater SIC at 10 to $60 \mathrm{~cm}$ in the grazing than in the chemical and mechanical treatments in CSW was likely a result of soil heterogeneity rather than the treatment effect, since SIC did not differ among treatments at other depths. 
Table 4. Analysis of variance for soil organic carbon (SOC), inorganic carbon (SIC), total nitrogen (STN), $\mathrm{NH}_{4}-\mathrm{N}$, and $\mathrm{NO}_{3}-\mathrm{N}$ contents in 2008.

\begin{tabular}{|c|c|c|c|c|c|c|c|}
\hline \multirow[b]{2}{*}{ Source } & \multicolumn{7}{|c|}{ Soil depth } \\
\hline & $0-5 \mathrm{~cm}$ & $5-10 \mathrm{~cm}$ & $10-30 \mathrm{~cm}$ & $30-60 \mathrm{~cm}$ & $60-90 \mathrm{~cm}$ & $90-120 \mathrm{~cm}$ & $0-120 \mathrm{~cm}$ \\
\hline & & & & SOC conten & & & \\
\hline Cropping sequence (CS) & nst & ns & ns & ns & ns & ns & ns \\
\hline Fallow management (FM) & ns & ns & $*$ & ns & ns & $*$ & ns \\
\hline \multirow[t]{2}{*}{$\mathrm{CS} \times \mathrm{FM}$} & ns & ns & $*$ & $*$ & ns & $* *$ & $*$ \\
\hline & & & & SIC content & & & \\
\hline CS & ns & ns & ns & ns & ns & ns & ns \\
\hline FM & ns & ns & ns & ns & ns & ns & ns \\
\hline \multirow[t]{2}{*}{$\mathrm{CS} \times \mathrm{FM}$} & ns & ns & ns & $*$ & ns & ns & ns \\
\hline & & & & $\underline{\text { STN content }}$ & & & \\
\hline CS & ns & ns & ns & $*$ & ns & $*$ & $*$ \\
\hline FM & ns & $*$ & ns & ns & ns & ns & ns \\
\hline \multirow[t]{2}{*}{$\mathrm{CS} \times \mathrm{FM}$} & $*$ & ns & ns & $* *$ & ns & ns & ns \\
\hline & & & & $\underline{\mathrm{NH}}_{4}-\mathrm{N}$ conte & & & \\
\hline CS & ns & ns & ns & ns & ns & ns & ns \\
\hline FM & ns & $*$ & ns & ns & ns & ns & ns \\
\hline \multirow[t]{2}{*}{$\mathrm{CS} \times \mathrm{FM}$} & ns & ns & ns & ns & ns & ns & ns \\
\hline & & & & $\mathrm{NO}_{3}-\mathrm{N}$ conte & & & \\
\hline CS & ns & ns & * & $*$ & $* * *$ & $* * *$ & $* * *$ \\
\hline FM & ns & ns & ns & ns & $*$ & ns & ns \\
\hline $\mathrm{CS} \times \mathrm{FM}$ & ns & ns & ns & ns & ns & ns & ns \\
\hline
\end{tabular}

* Significant at $P \leq 0.05$.

$* *$ Significant at $P \leq 0.01$.

*** Significant at $P \leq 0.001$

$\dagger$ Not significant.

\section{Soil Total Nitrogen}

Cropping sequence influenced STN content at 30 to 60,90 to 120 , and 0 to $120 \mathrm{~cm}$ and fallow management influenced the content at 5 to $10 \mathrm{~cm}$ in 2008 (Table 4). The cropping sequence $\times$ fallow management interaction was significant for STN content at 0 to 5 and 30 to $60 \mathrm{~cm}$.
In 2008 , STN content at 0 to $5 \mathrm{~cm}$ was greater in the chemical and mechanical than in the grazing treatment but at 30 to $60 \mathrm{~cm}$ was greater in the grazing than in the chemical treatment in CSW (Table 7). Averaged across fallow management practices, STN content at 30 to $60 \mathrm{~cm}$ was greater in CSW than in WW-F and at 90 to 120 and 0 to $120 \mathrm{~cm}$ was greater in CSW than in SW-F and WW-F. Averaged across cropping

Table 5. Effects of cropping sequence and fallow management practice on soil organic carbon (SOC) content at the 0 - to I20-cm depth in 2008.

\begin{tabular}{|c|c|c|c|c|c|c|c|c|}
\hline \multirow{2}{*}{$\begin{array}{l}\text { Cropping } \\
\text { sequence } \dagger\end{array}$} & \multirow{2}{*}{$\begin{array}{c}\text { Fallow } \\
\text { management } \ddagger\end{array}$} & \multicolumn{7}{|c|}{ SOC content } \\
\hline & & $0-5 \mathrm{~cm}$ & $5-10 \mathrm{~cm}$ & $10-30 \mathrm{~cm}$ & $30-60 \mathrm{~cm}$ & $60-90 \mathrm{~cm}$ & $90-120 \mathrm{~cm}$ & $0-120 \mathrm{~cm}$ \\
\hline & & & & & $\mathrm{MgC} \mathrm{ha} a^{-1}$ & & & \\
\hline \multirow[t]{3}{*}{ CSW } & Chem. & 18.2 & 18.4 & 60.0 & 32.8 & 30.3 & 23.3 & 183.0 \\
\hline & Mech. & 18.5 & 18.4 & 62.7 & 41.5 & 37.7 & 43.6 & 222.4 \\
\hline & Graz. & 16.6 & 18.6 & 55.4 & 39.9 & 30.0 & 30.8 & 191.2 \\
\hline \multirow[t]{3}{*}{ SW-F } & Chem. & 17.5 & 19.4 & 63.2 & 42.0 & 34.6 & 35.6 & 212.3 \\
\hline & Mech. & 16.6 & 16.7 & 55.1 & 33.8 & 34.0 & 34.9 & 191.2 \\
\hline & Graz. & I7.I & 17.1 & 53.1 & 36.2 & 31.8 & 28.1 & 183.4 \\
\hline \multirow[t]{3}{*}{ WW-F } & Chem. & 19.2 & 19.6 & 62.0 & 39.1 & 31.5 & 28.3 & 199.7 \\
\hline & Mech. & 16.8 & 17.2 & 56.9 & 38.7 & 35.8 & 32.4 & 197.7 \\
\hline & Graz. & 17.0 & 17.5 & 54.2 & 32.1 & 31.8 & 35.3 & 187.8 \\
\hline LSD (0.05) & & $\mathrm{ns} \S$ & ns & 5.5 & 7.7 & ns & 8.9 & 28.0 \\
\hline \multicolumn{9}{|l|}{ Means } \\
\hline & Chem. & I8.3aף & $19.2 \mathrm{a}$ & $61.7 \mathrm{a}$ & $38.0 \mathrm{a}$ & $32.2 \mathrm{a}$ & $29.1 \mathrm{~b}$ & $198.4 a$ \\
\hline & Mech. & $17.3 \mathrm{a}$ & $17.4 \mathrm{a}$ & $58.2 \mathrm{ab}$ & $38.0 \mathrm{a}$ & $35.8 \mathrm{a}$ & $37.0 \mathrm{a}$ & $203.5 a$ \\
\hline & Graz. & $16.9 \mathrm{a}$ & $17.7 \mathrm{a}$ & $54.2 \mathrm{~b}$ & 36. Ia & $31.2 \mathrm{a}$ & $31.4 \mathrm{ab}$ & 187.5a \\
\hline
\end{tabular}

† Cropping sequence are CSW, continuous spring wheat; SW-F, spring wheat-fallow; and WW-F, winter wheat-fallow.

‡ Fallow management practices are Chem., chemical where weeds were controlled with herbicides; Graz., grazing where weeds were controlled with sheep grazing; and Mech., mechanical where weeds were controlled with tillage.

$\S$ Not significant.

IT Numbers followed by different letters within a column are significantly different at $P=0.05$ by the least square means test. 
Table 6. Effects of cropping sequence and fallow management practice on soil inorganic carbon (SIC) content at the 0 - to I20-cm depth in 2008.

\begin{tabular}{|c|c|c|c|c|c|c|c|c|}
\hline \multirow{2}{*}{$\begin{array}{l}\text { Cropping } \\
\text { sequence } \dagger\end{array}$} & \multirow{2}{*}{$\begin{array}{c}\text { Fallow } \\
\text { management } \ddagger\end{array}$} & \multicolumn{7}{|c|}{ SIC content } \\
\hline & & $0-5 \mathrm{~cm}$ & $5-10 \mathrm{~cm}$ & $10-30 \mathrm{~cm}$ & $30-60 \mathrm{~cm}$ & $60-90 \mathrm{~cm}$ & $90-120 \mathrm{~cm}$ & $0-120 \mathrm{~cm}$ \\
\hline & & & & & $-\mathrm{MgC} \mathrm{ha}^{-1}$ & & & \\
\hline \multirow[t]{3}{*}{ CSW } & Chem. & 1.4 & 1.4 & 6.2 & 3.7 & 31.6 & 40.5 & 84.7 \\
\hline & Mech. & 1.2 & 1.2 & 1.9 & 4.6 & 49.8 & 57.4 & 116.2 \\
\hline & Graz. & 0.6 & 1.2 & 15.6 & 17.3 & 25.4 & 45.2 & 105.4 \\
\hline \multirow[t]{3}{*}{ SW-F } & Chem. & I.I & 0.8 & 4.2 & 3.5 & 30.4 & 48.8 & 88.5 \\
\hline & Mech. & 1.3 & 1.2 & 3.6 & 2.1 & 41.2 & 44.8 & 94.1 \\
\hline & Graz. & 0.8 & I.I & 8.1 & 9.3 & 30.8 & 44.6 & 94.6 \\
\hline \multirow[t]{3}{*}{ WW-F } & Chem. & 0.9 & I.I & 4.0 & 2.2 & 38.3 & 39.1 & 85.6 \\
\hline & Mech. & 1.3 & I.I & 3.5 & 6.0 & 45.1 & 46.1 & 103.0 \\
\hline & Graz. & 0.9 & 1.5 & 4.5 & 3.0 & 40.9 & 41.7 & 92.6 \\
\hline LSD $(0.05)$ & & nsई & ns & ns & 11.4 & ns & ns & ns \\
\hline
\end{tabular}

† Cropping sequence are CSW, continuous spring wheat; SW-F, spring wheat-fallow; and WW-F, winter wheat-fallow.

$\ddagger$ Fallow management practices are Chem., chemical where weeds were controlled with herbicides; Graz., grazing where weeds were controlled with sheep grazing; and Mech., mechanical where weeds were controlled with tillage.

$\S$ Not significant.

sequences, STN content at 5 to $10 \mathrm{~cm}$ was greater in the chemical than in the mechanical treatment.

The lower STN content at 0 to $5 \mathrm{~cm}$ in the grazing than in the chemical and mechanical treatments in CSW (Table 7) was probably a result of residue removal due to consumption by sheep during grazing, a finding similar to that observed for SOC. In contrast, greater STN content at 30 to $60 \mathrm{~cm}$ in the grazing than in the chemical treatment and similar trends at other depths, although not significant, in CSW suggests that sheep urine and feces returned to the soil during grazing probably enriched $\mathrm{N}$ in subsoil layers. It could be possible that sheep urine and feces may contain relatively higher $\mathrm{N}$ concentration. The fact that grazing increased STN content compared with other fallow management practices at all depths, except at 0 to $5 \mathrm{~cm}$, especially in
CSW was probably related to difference in biomass yields among cropping sequences. Biomass yield was greater in CSW than in SW-F and WW-F (Table 2). It could be possible that more wheat residue was consumed by sheep during grazing in CSW because of greater residue availability than in SW-F and WW-F. As a result, more sheep urine and feces could have returned to the soil in CSW, resulting in greater STN content in the grazing than in other fallow management treatments in this cropping sequence.

The greater STN content at 30 to 60,90 to 120 , and 0 to 120 $\mathrm{cm}$ in CSW than in SW-F and WW-F was probably related to the greater amount of wheat biomass residue returned to the soil. Biomass yield was 41 to $73 \%$ greater in CSW than in SW-F and WW-F (Table 2). Greater amount of residue

Table 7. Effects of cropping sequence and fallow management practice on soil total nitrogen (STN) content at the 0 - to 120 -cm depth in 2008.

\begin{tabular}{|c|c|c|c|c|c|c|c|c|}
\hline \multirow{2}{*}{$\begin{array}{l}\text { Cropping } \\
\text { sequence } \dagger\end{array}$} & \multirow{2}{*}{$\begin{array}{c}\text { Fallow } \\
\text { management } \ddagger\end{array}$} & \multicolumn{7}{|c|}{ STN content } \\
\hline & & $0-5 \mathrm{~cm}$ & $5-10 \mathrm{~cm}$ & $10-30 \mathrm{~cm}$ & $30-60 \mathrm{~cm}$ & $60-90 \mathrm{~cm}$ & $90-120 \mathrm{~cm}$ & $0-120 \mathrm{~cm}$ \\
\hline & & & & 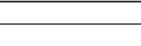 & $\mathrm{Mg} \mathrm{N} \mathrm{ha-1}$ & & & \\
\hline \multirow[t]{3}{*}{ CSW } & Chem. & 1.73 & 1.89 & 6.48 & 4.66 & 3.38 & 2.86 & 21.00 \\
\hline & Mech. & 1.72 & 1.78 & 6.24 & 5.29 & 3.64 & 3.26 & 21.93 \\
\hline & Graz. & 1.19 & 1.92 & 7.12 & 6.59 & 4.10 & 3.28 & 24.20 \\
\hline \multirow[t]{3}{*}{ SW-F } & Chem. & 1.51 & 1.90 & 6.66 & 5.24 & 3.84 & 2.82 & 21.97 \\
\hline & Mech. & 1.49 & 1.73 & 5.61 & 4.56 & 3.39 & 2.69 & 19.47 \\
\hline & Graz. & 1.75 & $\mathrm{I} .74$ & 6.14 & 5.36 & 3.73 & 2.69 & 21.40 \\
\hline \multirow[t]{3}{*}{ WW-F } & Chem. & 1.84 & 1.89 & 6.30 & 4.97 & 3.53 & 2.70 & 21.23 \\
\hline & Mech. & 1.62 & I.7I & 5.88 & 5.15 & 3.28 & 2.64 & 20.27 \\
\hline & Graz. & 1.66 & 1.73 & 5.73 & 4.83 & 3.74 & 3.00 & 20.60 \\
\hline LSD (0.05) & & 0.44 & ns $\S$ & ns & 1.34 & ns & ns & ns \\
\hline \multicolumn{9}{|l|}{ Means } \\
\hline CSW & & I.55aף & $1.86 \mathrm{a}$ & $6.6 \mathrm{Ia}$ & $5.5 \mathrm{la}$ & $3.7 \mathrm{Ia}$ & $3.13 a$ & $22.37 a$ \\
\hline SW-F & & $1.58 \mathrm{a}$ & $1.79 \mathrm{a}$ & $6.14 \mathrm{a}$ & $5.06 \mathrm{ab}$ & $3.65 a$ & $2.73 b$ & $20.94 b$ \\
\hline \multirow[t]{4}{*}{ WW-F } & & $1.70 \mathrm{a}$ & $1.78 \mathrm{a}$ & $5.97 a$ & $4.98 \mathrm{~b}$ & $3.52 \mathrm{a}$ & $2.78 b$ & $20.73 b$ \\
\hline & Chem. & $1.69 \mathrm{a}$ & $1.89 \mathrm{a}$ & $6.48 \mathrm{a}$ & $4.96 a$ & $3.58 \mathrm{a}$ & $2.79 a$ & $21.40 \mathrm{a}$ \\
\hline & Mech. & $\mathrm{I} .6 \mathrm{Ia}$ & $1.74 b$ & $5.91 \mathrm{a}$ & $5.00 \mathrm{a}$ & $3.43 a$ & $2.99 a$ & $20.55 a$ \\
\hline & Graz. & $1.53 \mathrm{a}$ & I.79ab & $6.33 a$ & $5.60 \mathrm{a}$ & $3.86 \mathrm{a}$ & $2.87 \mathrm{a}$ & $22.09 a$ \\
\hline
\end{tabular}

† Cropping sequence are CSW, continuous spring wheat; SW-F, spring wheat-fallow; and WW-F, winter wheat-fallow.

$\ddagger$ Fallow management practices are Chem., chemical where weeds were controlled with herbicides; Graz., grazing where weeds were controlled with sheep grazing; and Mech., mechanical where weeds were controlled with tillage.

$\S$ Not significant.

TI Numbers followed by different letters within a column in a set are significantly different at $P=0.05$ by the least square means test. 
Table 8. Effects of cropping sequence and fallow management practice on soil $\mathrm{NO}_{3}-\mathrm{N}$ content at the 0 - to $60-\mathrm{cm}$ depth from 2004 to 2007.

\begin{tabular}{|c|c|c|c|c|}
\hline \multirow[b]{2}{*}{ Year } & \multirow{2}{*}{$\begin{array}{l}\text { Cropping } \\
\text { sequence }\end{array}$} & \multicolumn{3}{|c|}{$\mathrm{NO}_{3}-\mathrm{N}$ content } \\
\hline & & $0-15 \mathrm{~cm}$ & $15-30 \mathrm{~cm}$ & $30-60 \mathrm{~cm}$ \\
\hline & & $\longrightarrow$ & $\mathrm{kg} \mathrm{N} \mathrm{ha}{ }^{-1}$ & $\longrightarrow$ \\
\hline \multirow[t]{3}{*}{2004} & CSW & 21.5 & 5.3 & 5.2 \\
\hline & SW-F & 44.5 & 17.1 & 19.8 \\
\hline & WW-F & 31.6 & 7.3 & 6.0 \\
\hline \multirow[t]{3}{*}{2005} & CSW & 21.8 & 7.2 & 9.6 \\
\hline & SW-F & 37.0 & 12.4 & 18.4 \\
\hline & WW-F & 40.4 & 12.7 & 13.4 \\
\hline \multirow[t]{3}{*}{2006} & CSW & 17.0 & 3.5 & 4.4 \\
\hline & SW-F & 24.8 & 12.4 & 12.4 \\
\hline & WW-F & 29.8 & 13.6 & 10.8 \\
\hline \multirow[t]{3}{*}{2007} & CSW & 16.6 & 9.3 & 16.8 \\
\hline & SW-F & 17.4 & 9.2 & 15.8 \\
\hline & WW-F & 19.3 & 9.6 & 16.4 \\
\hline LSD (0.05) & & 12.8 & 7.0 & 6.6 \\
\hline \multicolumn{5}{|l|}{ Means } \\
\hline 2004 & & $32.5 a \ddagger$ & $9.9 a$ & $10.4 b$ \\
\hline 2005 & & $33.0 \mathrm{a}$ & $10.8 \mathrm{a}$ & $13.8 \mathrm{ab}$ \\
\hline 2006 & & $23.9 b$ & $9.8 \mathrm{a}$ & $9.0 \mathrm{~b}$ \\
\hline \multirow[t]{4}{*}{2007} & & $17.8 \mathrm{~b}$ & $9.4 a$ & $16.4 \mathrm{a}$ \\
\hline & CSW & $19.2 b$ & $6.3 \mathrm{~b}$ & $9.0 \mathrm{~b}$ \\
\hline & SW-F & $30.9 \mathrm{a}$ & $12.8 \mathrm{a}$ & $16.6 \mathrm{a}$ \\
\hline & WW-F & $30.3 a$ & $10.8 \mathrm{a}$ & $11.6 \mathrm{~b}$ \\
\hline \multicolumn{5}{|c|}{ Analysis of variance } \\
\hline \multicolumn{2}{|c|}{ Cropping sequence (CS) } & $* * *$ & $* *$ & $* * *$ \\
\hline \multicolumn{2}{|c|}{ Fallow management (FM) } & ns $\S$ & ns & ns \\
\hline \multicolumn{2}{|c|}{$\mathrm{CS} \times \mathrm{FM}$} & ns & ns & ns \\
\hline \multicolumn{2}{|l|}{ Year (Yr) } & $* * *$ & ns & $* * *$ \\
\hline \multicolumn{2}{|l|}{$\mathrm{CS} \times \mathrm{Yr}$} & $*$ & $*$ & ** \\
\hline \multicolumn{2}{|l|}{$\mathrm{FM} \times \mathrm{Yr}$} & ns & ns & ns \\
\hline \multicolumn{2}{|c|}{$\mathrm{CS} \times \mathrm{FM} \times \mathrm{Yr}$} & ns & ns & ns \\
\hline \multicolumn{5}{|c|}{ * Significant at $P \leq 0.05$} \\
\hline \multicolumn{5}{|c|}{$* *$ Significant at $P \leq 0.01$} \\
\hline \multicolumn{5}{|c|}{$* * *$ Significant at $P \leq 0.001$} \\
\hline \multicolumn{5}{|c|}{$\begin{array}{l}\text { † Cropping sequence are CSW, continuous spring wheat; SW-F, spring wheat- } \\
\text { fallow; and WW-F, winter wheat-fallow. }\end{array}$} \\
\hline \multirow{2}{*}{\multicolumn{5}{|c|}{$\begin{array}{l}\ddagger \text { Numbers followed by different letters within a column in a set are significantly } \\
\text { different at } P=0.05 \text { by the least square means test. } \\
\delta \text { Not significant. }\end{array}$}} \\
\hline$\S$ Not significant. & & & & \\
\hline
\end{tabular}

returned to the soil can increase STN, similar to SOC (Sherrod et al., 2003; Sainju et al., 2009a).

\section{Soil Ammonium- and Nitrate-Nitrogen}

From 2004 to $2007, \mathrm{NO}_{3}-\mathrm{N}$ content at 0 to 15,15 to 30 , and 30 to $60 \mathrm{~cm}$ was significantly influenced by cropping sequence (Table 8). Year was significant for $\mathrm{NO}_{3}-\mathrm{N}$ content 0 to 15 and 30 to $60 \mathrm{~cm}$. Similarly, cropping sequence $\times$ year interaction was significant for $\mathrm{NO}_{3}-\mathrm{N}$ content at 0 to 15,15 to 30 , and 30 to $60 \mathrm{~cm}$.

Averaged across fallow management practices, $\mathrm{NO}_{3}-\mathrm{N}$ content at 0 to 15 and 30 to $60 \mathrm{~cm}$ was greater in SW-F or WW-F than in CSW from 2004 to 2006 (Table 8). At 15 to $30 \mathrm{~cm}, \mathrm{NO}_{3}-\mathrm{N}$ content was also greater in SW-F or WW-F than in CSW in 2004 and 2006. Averaged across treatments, $\mathrm{NO}_{3}-\mathrm{N}$ content at 0 to $15 \mathrm{~cm}$ decreased linearly from 2004 to 2007 at $5.3 \mathrm{~kg} \mathrm{~N}$ $\mathrm{ha}^{-1} \mathrm{yr}^{-1}\left(R^{2}=0.88, P \leq 0.06, n=4\right)$. The $\mathrm{NO}_{3}-\mathrm{N}$ content at 0 to $15 \mathrm{~cm}$ was also linearly related with SOC concentration $\left(R^{2}=\right.$ $0.86, P \leq 0.07, n=4)$. At 30 to $60 \mathrm{~cm}, \mathrm{NO}_{3}-\mathrm{N}$ content was greater in 2007 than in 2004 and 2006. Averaged across fallow management practices and years, $\mathrm{NO}_{3}-\mathrm{N}$ content at 0 to 15 and 15 to $30 \mathrm{~cm}$ was greater in SW-F and WW-F than in CSW and at 30 to $60 \mathrm{~cm}$ was greater in SW-F than in CSW and WW-F.

In $2008, \mathrm{NH}_{4}-\mathrm{N}$ content was not significant for treatments and interaction (Table 4). The $\mathrm{NO}_{3}-\mathrm{N}$ content at 10 to 120 and 0 to $120 \mathrm{~cm}$ was influenced by cropping sequence. Similarly, $\mathrm{NO}_{3}-\mathrm{N}$ content at 60 to $90 \mathrm{~cm}$ was influenced by the fallow management practice. Averaged across fallow management practices, $\mathrm{NO}_{3}-\mathrm{N}$ content at 10 to $30 \mathrm{~cm}$ was greater in SW-F than in CSW (Table 9). At 30 to 120 and 0 to $120 \mathrm{~cm}, \mathrm{NO}_{3}-\mathrm{N}$ content was greater in CSW and SW-F than in WW-F. Averaged across cropping sequences, $\mathrm{NO}_{3}-\mathrm{N}$ content at 60 to $90 \mathrm{~cm}$ was greater in the mechanical than in the chemical treatment.

The greater $\mathrm{NO}_{3}-\mathrm{N}$ content at 0 to $60 \mathrm{~cm}$ in SW-F and WW-F than in CSW from 2004 to 2006 was probably due to reduced N uptake by wheat due to absence of crops during fallow, followed by increased soil $\mathrm{N}$ mineralization during fallow. Increased soil temperature and water content during fallow increase microbial activities and $\mathrm{N}$ mineralization (Eck and Jones, 1992; Halvorson et al., 2002), thereby resulting in increased $\mathrm{NO}_{3}-\mathrm{N}$ content in SW-F and WW-F. Continuous cropping increased crop yield (Table 2) and probably $\mathrm{N}$ uptake, thereby reducing $\mathrm{NO}_{3}-\mathrm{N}$ level in CSW compared with SW-F and WW-F. Wood et al. (1990) found that soil profile $\mathrm{NO}_{3}-\mathrm{N}$ content decreased with increased cropping

Table 9. Effects of cropping sequence and fallow management practice on soil $\mathrm{NO}_{3}-\mathrm{N}$ content at the 0 - to I20-cm depth in 2008 .

\begin{tabular}{|c|c|c|c|c|c|c|c|}
\hline \multirow[b]{2}{*}{ Treatment } & \multicolumn{7}{|c|}{$\mathrm{NO}_{3}-\mathrm{N}$ content } \\
\hline & $0-5 \mathrm{~cm}$ & $5-10 \mathrm{~cm}$ & $10-30 \mathrm{~cm}$ & $30-60 \mathrm{~cm}$ & $60-90 \mathrm{~cm}$ & $90-120 \mathrm{~cm}$ & $0-120 \mathrm{~cm}$ \\
\hline & & & & $\mathrm{kg} \mathrm{N} \mathrm{ha-l}$ & & & 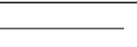 \\
\hline \multicolumn{8}{|c|}{ Cropping sequence $\dagger_{-}$} \\
\hline CSW & $10.4 \mathrm{a} \ddagger$ & $12.0 \mathrm{a}$ & $16.2 \mathrm{~b}$ & $18.2 \mathrm{a}$ & $28.0 \mathrm{a}$ & $55.3 \mathrm{a}$ & $140.1 \mathrm{a}$ \\
\hline SW-F & $12.2 \mathrm{a}$ & $12.7 \mathrm{a}$ & $23.6 a$ & $17.2 \mathrm{a}$ & $29.9 a$ & 35.16 & $130.7 \mathrm{a}$ \\
\hline WW-F & $10.2 \mathrm{a}$ & $10.7 \mathrm{a}$ & $20.7 a b$ & $12.5 b$ & $13.0 \mathrm{~b}$ & $20.2 c$ & $87.3 b$ \\
\hline \multicolumn{8}{|c|}{ Fallow management $\oint_{-}$} \\
\hline Chem. & $12.6 \mathrm{a}$ & $12.4 \mathrm{a}$ & $20.6 a$ & $16.0 \mathrm{a}$ & $18.9 b$ & $38.0 \mathrm{a}$ & $118.6 \mathrm{a}$ \\
\hline Mech. & $10.3 \mathrm{a}$ & $12.0 \mathrm{a}$ & $21.1 \mathrm{a}$ & $14.5 \mathrm{a}$ & $28.8 \mathrm{a}$ & $37.6 a$ & $124.4 \mathrm{a}$ \\
\hline Graz. & $9.9 a$ & $10.9 \mathrm{a}$ & $18.7 \mathrm{a}$ & $17.5 \mathrm{a}$ & $23.2 \mathrm{ab}$ & $35.0 \mathrm{a}$ & $1 \mid 5.2 \mathrm{a}$ \\
\hline
\end{tabular}

† Cropping sequence are CSW, continuous spring wheat; SW-F, spring wheat-fallow; and WW-F, winter wheat-fallow.

$\ddagger$ Numbers followed by different letters within a column in a set are significantly different at $P=0.05$ by the least square means test.

$\S$ Fallow management practices are Chem., chemical where weeds were controlled with herbicides; Graz., grazing where weeds were controlled with sheep grazing; and Mech., mechanical where weeds were controlled with tillage. 
intensity due to greater $\mathrm{N}$ immobilization, less summer fallow, and greater amount of $\mathrm{N}$ removed by crops. Increasing fallow period can increase $\mathrm{N}$ loss below the root zone due to leaching and absence of crops to conserve $\mathrm{N}$ (Eck and Jones, 1992).

The lower $\mathrm{NO}_{3}-\mathrm{N}$ content at 30 to $120 \mathrm{~cm}$ in WW-F than in CSW and SW-F in 2008 (Table 9) was probably a result of either reduced $\mathrm{N}$ fertilization rate or increased $\mathrm{N}$ uptake by winter wheat due to increased root growth at the subsoil layers, since winter wheat in WW-F had 11 mo of growing period compared with 4 mo for spring wheat in CSW and SW-F. Nitrogen fertilization rate for winter wheat in WW-F was $50 \mathrm{~kg} \mathrm{~N} \mathrm{ha}^{-1}$ lower than for spring wheat in SW-F. In contrast, wheat grain and biomass yields were greater in WW-F than in SW-F in 2008 (Table 2). While lower N uptake by spring wheat could have increased $\mathrm{NO}_{3}-\mathrm{N}$ content in CSW, greater uptake by winter wheat due to increased yield could have reduced $\mathrm{NO}_{3}-\mathrm{N}$ content in WW-F compared with SW-F.

The significant relationships among soil $\mathrm{NO}_{3}-\mathrm{N}$ content, year, and $\mathrm{SOC}$ concentration at 0 to $15 \mathrm{~cm}$ suggests that $\mathrm{NO}_{3}-\mathrm{N}$ level declined from 2004 to 2007 probably due to reduced soil organic matter level as a result of increased mineralization due to tillage and/or reduced residue input (Table 2). Since SOC and STN are linearly related (Kuo et al., 1997), reduced SOC also probably reduced STN level, thereby resulting in reduced $\mathrm{NO}_{3}-\mathrm{N}$ content. In contrast, greater $\mathrm{NO}_{3}-\mathrm{N}$ content at 30 to $60 \mathrm{~cm}$ in 2007 than in 2004 and 2006 (Table 8) indicates that $\mathrm{N}$ accumulated in the subsoil layer as a result of leaching from overlying layers. Substantial rainfall from April to June 2007 (Table 1) probably leached $\mathrm{NO}_{3}-\mathrm{N}$ from overlying layers and accumulated in the subsoil layers where only few roots can take up $\mathrm{N}$.

\section{SUMMARY AND CONCLUSIONS}

Sheep grazing for weed control during fallow periods had minor influence on soil $\mathrm{NH}_{4}-\mathrm{N}$ and $\mathrm{NO}_{3}-\mathrm{N}$ levels and wheat grain and biomass yields compared with tillage and herbicide application methods. In contrast, sheep grazing reduced soil C storage after $5 \mathrm{yr}$, especially in CSW and SW-F but a slight positive effect on subsurface $\mathrm{N}$ storage in CSW. Soil $\mathrm{N}$ storage and wheat grain and biomass yields were greater but $\mathrm{NO}_{3}-\mathrm{N}$ content was lower in CSW than in SW-F and WW-F, probably due to continuous cropping and increased $\mathrm{N}$ uptake. Similarly, $\mathrm{NO}_{3}-\mathrm{N}$ content was lower in WW-F than in CSW and SW-F in 2008, probably a result of reduced $\mathrm{N}$ fertilization rate or increased $\mathrm{N}$ uptake by winter wheat due to increased root growth. Continuous tillage, followed by reduced amount of wheat residue returned to the soil, probably reduced soil $\mathrm{C}$ and $\mathrm{NO}_{3}-\mathrm{N}$ levels from 2004 to 2007 . For sustaining soil organic matter and wheat yields and reducing $\mathrm{N}$ leaching loss, reduced tillage with continuous wheat cropping and less intensive sheep grazing could be used as an option to increase the amount of biomass residue returned to the soil and reduce soil $\mathrm{C}$ and $\mathrm{N}$ mineralization under dryland cropping systems in the northern Great Plains.

\section{REFERENCES}

Aase, J.K., and J.L. Pikul, Jr. 1995. Crop and soil response to long-term tillage practices in the northern Great Plains. Agron. J. 87:652-656.

Abaye, A.O., V.G. Allen, and J.P. Fontenot. 1997. Grazing sheep and cattle together or separately: Effects on soils and plants. Agron. J. 89:380-386.

Bauer, A., and A.L. Black. 1994. Quantification of the effect of soil organic matter content on soi productivity. Soil Sci. Soc. Am. J. 58:185-193.

Black, A.L., and A. Bauer. 1988. Strategies for storing and conserving soil water in the northern Grea Plains. p. 137-139. In P.W. Unger et al. (ed.) Proc. Int. Conf. on Dryland Farming, Bushland, TX. 15-19 Aug. 1988. Texas Agric. Exp. Stn., College Station.
Bowman, R.A., M.F. Vigil, D.C. Nielsen, and R.L. Anderson. 1999. Soil organic matter changes in intensively cropped dryland systems. Soil Sci. Soc. Am. J. 63:186-191.

Campbell, C.A., R.P.Zentner, B.C. Liang, G. Roloff, E.C. Gregorich, and B. Blomert. 2000. Organic carbon accumulation in soil over 30 years in semiarid southwestern Saskatchewan: Effect of crop rotations and fertilizers. Can. J. Soil Sci. 80:170-192.

Eck, H.V., and O.R. Jones. 1992. Soil nitrogen status as affected by tillage, crops, and crop sequences Agron. J. 84:660-668.

Entz, M.H., V.S. Baron, P.M. Carr, D.W. Meyer, S.R. Smith, Jr., and W.P. McCaughey. 2002. Potential of forages to diversify cropping systems in the Northern Great Plains. Agron. J. 94:240-250.

Fenster, C.R. 1997. Conservation tillage in the northern Great Plains. J. Soil Water Conserv $32: 37-42$.

Franzluebbers, A.J. 2007. Integrated crop-livestock systems in the southeastern USA. Agron. J 99:361-372.

Franzluebbers, A.J., and J.A. Stuedemann. 2008. Early response of soil organic fractions to tillage and integrated crop-livestock production. Soil Sci. Soc. Am. J. 72:613-625.

Goosey, H.B., P.G. Hatfield, A.W. Lenssen, S.L. Blodgett, and R.W. Kott. 2005. The potential role of sheep in dryland grain production systems. Agric. Ecosyst. Environ. 111:349-353.

Halvorson, A.D., A.L. Black, J.M. Krupinsky, S.D. Merrill, B.J. Wienhold, and D.L. Tanaka. 2000. Spring wheat response to tillage and nitrogen fertilization in rotation with sunflower and winter wheat. Agron. J. 92:136-144.

Halvorson, A.D., B.J. Wienhold, and A.L. Black. 2002. Tillage, nitrogen, and cropping system effects on soil carbon sequestration. Soil Sci. Soc. Am. J. 66:906-912.

Hatfield, P.G., S.L. Blodgett, T.M. Spezzano, H.B. Goosey, A.W. Lenssen, R.W. Kott, and C.B. Marlow. 2007a. Incorporating sheep into dryland grain production systems. I. Impact on overwintering larval populations of wheat stem sawfly, Cephus cinctus Norton (Hymenoptera: Cephidae). Small Rumin. Res. 67:209-215.

Hatfield, P.G., H.B. Goosey, T.M. Spezzano, S.L. Blodgett, A.W. Lenssen, and R.W. Kott. 2007b. Incorporating sheep into dryland grain production systems. III. Impact on changes in soil bulk density and soil nutrient profiles. Small Rumin. Res. 67:222-232.

Hatfield, P.G., A.W. Lenssen, T.M. Spezzano, S.L. Blodgett, H.B. Goosey, R.W. Kott, and C.B. Marlow. 2007c. Incorporating sheep into dryland grain production systems. II. Impact on changes in biomass and weed density. Small Rumin. Res. 67:216-221.

Herrero, M., P.K. Thorton, A.M. Notenbaert, S. Wood, S. Msangi, H.A. Freeman, D. Bossio, J. Dixon, M. Peters, J. van de Steeg, J. Lynam, P. Parthasarathy Rao, S. Macmillan, B. Gerard J. McDermont, C. Sere, and M. Rosegrant. 2010. Smart investments in sustainable food productions: Revisiting mixed crop-livestock systems. Science (Washington, DC) 327:822-825.

Johnson, J.B., W.E.Zidack, S.M. Capalbo, J.M. Antle, and D.F. Webb. 1997. Pests, pesticide use, and pesticide costs on larger central and eastern Montana farms with annually-planted dryland crops. Spec. Rep. 23. Dep. Agric. Econ., Montana State Univ., Bozeman.

Jones, O.R., and T.W. Popham. 1997. Cropping and tillage systems for dryland grain production in southern High Plains. Agron. J. 89:222-232.

Kuo, S., U.M. Sainju, and E.J. Jellum. 1997. Winter cover cropping influence on nitrogen in soil. Soil Sci. Soc. Am. J. 61:1392-1399.

Landau, S., I. Schoembaum, D. Barkar, E.D. Unger, A. Genizi, and J. Kigel. 2007. Grazing, mulch ing, and removal of wheat straw in a no-till system in a semi-arid environment. Aust. J. Agric. Res. 58:907-912.

Lenssen, A.W., G.D. Johnson, and G.R. Carlson. 2007. Cropping sequence and tillage system influences annual crop production and water use in semiarid Montana. Field Crops Res. 100:32-43.

Littell, R.C., G.A. Milliken, W.W. Stroup, and R.D. Wolfinger. 1996. SAS system for mixed models. SAS Inst., Cary, NC.

Maughan, M.W., J.P.C. Flores, I. Anghinoni, G. Bollero, F.G. Fernandez, and B.G. Tracy. 2009. Soi quality and corn yield under crop-livestock integration in Illinois. Agron. J. 101:1503-1510.

Merrill, S.D., A.L. Black, and A. Bauer. 1996. Conservation tillage affects root growth of dryland spring wheat under drought. Soil Sci. Soc. Am. J. 60:575-583.

Nelson, D.W., and L.E. Sommers. 1996. Total carbon, organic carbon, and organic matter. p. 9611010. In D.L. Sparks et al. (ed.) Methods of soil analysis. Part 3. Chemical methods. SSSA Book Ser. 5. SSSA, Madison, WI.

Ortega, R.A., G.A. Peterson, and D.G. Westfall. 2002. Residue accumulation and changes in soil organic matter as affected by cropping intensity in no-till dryland agroecosystems. Agron. J. 94:944-954.

Redmon, L.A., G.W. Horn, E.G. Krenzer, Jr., and D.J. Bernardo. 1995. A review of livestock grazing and wheat grain yield: Boom or bust. Agron. J. 87:137-147.

Sainju, U.M., T. Caesar-TonThat, A.W. Lenssen, R.G. Evans, and R. Kolberg. 2007. Long-term tillage and cropping sequence effects on dryland residue and soil carbon fractions. Soil Sci. Soc. Am. J. 71:1730-1739

Sainju, U.M., T. Caesar-TonThat, A.W. Lenssen, R.G. Evans, and R. Kohlberg. 2009a. Tillage and cropping sequence impacts on nitrogen cycling in dryland farming in eastern Montana, USA. Soil Tillage Res. 103:332-341.

Sainju, U.M., A.W. Lenssen, T. Caesar-TonThat, and R.G. Evans. 2009b. Dryland crop yields and soil organic matter as influenced by long-term tillage and cropping sequence. Agron. J. 101:243-251

Sainju, U.M., A.W. Lenssen, T. Caesar-Tonthat, and J. Waddell. 2006. Tillage and crop rotation effects on dryland soil and residue carbon and nitrogen. Soil Sci. Soc. Am. J. 70:668-678

Schomberg, H.H., and O.R. Jones. 1999. Carbon and nitrogen conservation in dryland tillage and cropping systems. Soil Sci. Soc. Am. J. 63:1359-1366.

Sherrod, L.A., G.A. Peterson, D.G. Westfall, and L.R. Ahuja. 2003. Cropping intensity enhances soil organic carbon and nitrogen in a no-till agroecosystem. Soil Sci. Soc. Am. J. 67:1533-1543.

Snyder, E.E.. H.B. Goosey, P.G. Hatfield, and A.W. Lenssen. 2007. Sheep grazing on wheat-summer fallow and the impact on soil nitrogen, moisture, and crop yield. p. 221-224. In R. Battaglia (ed.) Proc. Western Section, Am. Soc. Anim. Sci. Vol. 58, Moscow, ID. 20-22 June 2007. Am Soc. Animal Sci. Western Section, Champaign, IL.

Tanaka, D.L., and J.K. Aase. 1987. Fallow method influences on soil water and precipitation storage efficiency. Soil Tillage Res. 9:307-316.

Tracy, B.J., and Y.Zhang. 2008. Soil compaction, corn yield response, and soil nutrient pool dynamics within an integrated crop-livestock system in Illinois. Crop Sci. 48:1211-1218.

Wood, C.W., D.G. Westfall, G.A. Peterson, and I.C. Burke. 1990. Impacts of cropping intensity on carbon and nitrogen mineralization under no-till agroecosystems. Agron. J. 82:1115-1120. 